\title{
PROBLEM ZACHODNIEJ GRANICY POLSKI ORAZ ZJEDNOCZENIA NIEMIEC W POLITYCE ZAGRANICZNEJ RZĄDU TADEUSZA MAZOWIECKIEGO (1989-1990)1
}

\author{
Antoni Dudek \\ Uniwersytet Kardynała Stefana Wyszyńskiego w Warszawie
}

\begin{abstract}
THE QUESTION OF THE POLISH WESTERN BORDER AND THE GERMAN REUNIFICATION IN THE INTERNATIONAL POLICIES OF THE GOVERNMENT OF TADEUSZ MAZOWIECKI (1989-1990)
\end{abstract}

Following the fall of the Berlin Wall, the main problem in the international policies of Tadeusz Mazowiecki's government was to guarantee the Polish western border before the reunification of Germany took place. In the face of Chancellor Helmut Kohl's opposition to the idea, the Polish government undertook a wide diplomatic action trying to convince the leaders of the USSR, USA, Great Britain and France to make the governments of the FRG and GDR initiate a border treaty before the reunification of both German states. Finally, Mazowiecki's government managed to safeguard the participation of its representative in the Two Plus Four Conference, at which the conditions for the reunification were established. One of them was about the confirmation of the border between Germany and Poland and abandonment of any territorial claims in the future.

Key words: Poland, Germany, German reunification, Polish western border, Tadeusz Mazowiecki's government.

Słowa kluczowe: Polska, Niemcy, zjednoczenie Niemiec, polska granica zachodnia, rząd Tadeusza Mazowieckiego.

${ }^{1}$ Tekst powstał w ramach grantu „Rządy solidarnościowe w Polsce w latach 1989-1993 wobec podstawowych problemów transformacji ustrojowej" finansowanego przez Narodowe Centrum Nauki zgodnie z umową UMO-2014/15/B/HS3/02290.

Adres do korespondencji: akdudek@interia.pl 
We wrześniu 1989 roku, a zatem w chwili powstania rządu Tadeusza Mazowieckiego, problem zjednoczenia obu państw niemieckich wydawał się tematem jeśli nie całkowicie abstrakcyjnym, to z pewnością bardzo odległym. Dlatego w exposé, jakie Mazowiecki przedstawił w Sejmie 12 września 1989 roku, mówiąc o ,potrzebie przełomu" w stosunkach z Republiką Federalną Niemiec, miał na myśli przede wszystkim zainicjowanie procesu ,prawdziwego pojednania na miarę tego, jakie się dokonało między Niemcami i Francuzami"'. Znaczenia, jakie premier Mazowiecki przywiązywał do tej sprawy, dowodzi pierwsza rozmowa telefoniczna, którą odbył z kanclerzem RFN Helmutem Kohlem już 31 sierpnia, a także powołanie - jako swojego osobistego pełnomocnika ds. rozmów z RFN - redaktora „Tygodnika Powszechnego" Mieczysława Pszona, należącego do grona najbardziej zaufanych współpracowników szefa rządu ${ }^{3}$. „Już w czasie tej pierwszej rozmowy ustaliliśmy, że trzeba przezwyciężyć impas w stosunkach Polska-RFN" - mówił później na ten temat Mazowiecki i dodawał, że ,,wśród ludzi ze starego aparatu występowały pewne uprzedzenia, na przykład że nie możemy uregulować jasno i wyraźnie problemu mniejszości, że on nam odżyje, że Śląsk będzie przez to zagrożony"4. Istotne znaczenie miała tu osoba prezydenta Wojciecha Jaruzelskiego, którego rola w kształtowaniu polskiej polityki zagranicznej była od jesieni 1989 roku wprawdzie drugoplanowa, ale z uwagi na obawy Mazowieckiego przed destabilizacją wewnętrzną liczył się on bardzo ze stanowiskiem gospodarza Belwederu aż do końca swoich rządów.

Pszon zajął miejsce Ernesta Kuczy, kierownika Wydziału Zagranicznego KC PZPR, który pełnił funkcję pełnomocnika premiera Mieczysława F. Rakowskiego i w tej roli przeprowadził już w pierwszej połowie 1989 roku siedem rund rozmów z przedstawicielem Kohla, Horstem Teltschikiem. Koncentrowały się one wokół kwestii związanych z obsługą zadłużenia PRL w RFN i ewentualnych nowych kredytów, a także ze statusem mniejszości niemieckiej w Polsce. Wobec bardzo szybkiego procesu zmian politycznych zachodzących w Polsce rozmowy zostały zawieszone w czerwcu, a ich wznowienie - już z udziałem Pszona - nastąpiło w połowie września 1989 roku. Niespodziewanie na atmosferę tych rozmów wpłynął problem obywateli NRD, którzy w ambasadzie RFN w Warszawie - tak jak wcześniej na znacznie większą skalę w Budapeszcie i Pradze - zaczęli szukać możliwości ucieczki do Niemiec Zachodnich5.

Zajęcie stanowiska w sprawie uciekinierów z NRD stało się pierwszym wyzwaniem dla prof. Krzysztofa Skubiszewskiego, który objął w rządzie Mazowieckiego stanowisko szefa MSZ. 13 września 1989 roku, a zatem nazajutrz po powołaniu przez Sejm, Skubiszewski przyjął dyrektora Departamentu Politycznego zachodnioniemieckiego MSZ Dietera Kastrupa, który starał się go przekonać, by nowy polski

\footnotetext{
2 Stenogram 7 posiedzenia Sejmu w dniu 12 września 1989 r., s. 20, www.sejm.gov.pl [dostęp: 10.04.2017].

3 Zob. Polacy i Niemcy pót wieku później. Księga pamiątkowa dla Mieczysława Pszona, red. W. Pięc i ak, Kraków 1996, s. 540-547.

${ }^{4}$ T. Mazow ie cki, Rok 1989 i lata nastepne. Teksty wybrane $i$ nowe, Warszawa 2012, s. 96, 99.

5 A. Gubrynowicz, NRD - przegrana rewolucja? [w:] A. Burakowski, A. Gubrynowicz, P. Ukielski, 1989 - Jesień Narodów, Warszawa 2010, s. 127; C.J. D u is berg, Das deutsche Jahr. Einblicke in der Wiedervereinigung 1989/1990, Berlin 2005, s. 47-61.
} 
rząd zastosował w tej sprawie tzw. rozwiązanie węgierskie. Chodziło tu o decyzję ogłoszoną 10 września przez rząd Węgier o otwarciu granicy z Austrią, co umożliwiło wyjazd około 15 tys. obywateli $\mathrm{NRD}^{6}$. Kastrup powoływał się w tej sprawie na przewodniczącego NSZZ Solidarność Lecha Wałęsę, który - przebywając kilka dni wcześniej z wizytą w RFN - miał zadeklarować ministrowi spraw zagranicznych Hansowi-Dietrichowi Genscherowi poparcie dla takiego rozwiązania. Wałęsa nie pełnił wówczas żadnych funkcji państwowych, ale jego deklaracja miała spore znaczenie polityczne, co było o tyle istotne, że różniła się od stanowiska rządu. Dlatego Skubiszewski dyplomatycznie stwierdził, że nie zdążył się zapoznać z przebiegiem rozmowy Wałęsa-Genscher, a najlepszym rozwiązaniem kwestii uciekinierów byłoby ,polubowne rozwiązanie sprawy między władzami NRD i RFN"7. Ten punkt widzenia był podtrzymywany w następnych dniach, co przypuszczalnie doprowadziłoby do impasu na linii Warszawa-Bonn, gdyby nie stopniowe ustępstwa ze strony władz NRD, które zgodziły się na wyjazd uciekinierów z Warszawy i Pragi do RFN przez swoje terytorium w zaplombowanych wagonach. Zanim to jednak nastąpiło, istotne znaczenie miał fakt, że rząd Mazowieckiego podjął decyzję o ignorowaniu porozumienia z NRD, umożliwiającego deportowanie obywateli tego kraju ${ }^{8}$.

Uruchomienie tzw. pociągów wolności - w których do RFN wyjechało z Polski w sumie ponad 5 tys. Niemców - pogłębiło ferment w NRD, a zarazem ułatwiło osiągnięcie ostatecznego porozumienia między Pszonem a Teltschikiem. Jego ramy doprecyzowano podczas ósmej rundy rozmów, do jakiej doszło w dniach 14-16 września w Warszawie. W ich trakcie nie rozmawiano wprawdzie o kwestii uchodźców, ale - jak podkreślał w swoim sprawozdaniu Pszon - rysujące się porozumienie miało nastąpić ,,przy założeniu, że sprawa obywateli NRD w Ambasadzie RFN w Warszawie zostanie rozwiązana bez obciążania naszych stosunków z Bonn"9. Ponieważ tak właśnie się stało, a polskie władze zaangażowały się nawet w ochronę samochodów porzucanych na ulicach Warszawy przez Niemców uciekających do znajdującej się wówczas przy ulicy Dąbrowieckiej ambasady RFN, dziewiąta runda rozmów przeprowadzona na początku października zakończyła się sukcesem. W jej trakcie osiągnięto porozumienie w dwóch najtrudniejszych sprawach: kwestiach finansowych oraz uregulowania praw mniejszości narodowych w obu krajach. Wprawdzie w tekście porozumienia wciąż nie było mowy o mniejszościach,

\footnotetext{
${ }^{6}$ Na temat okoliczności, w jakich podjęto tę decyzję, zob. G. Hor n, Jak zerwano żelazna kurtynę?, „Polityka”, 21 marca 1992.

7 Polska wobec zjednoczenia Niemiec 1989-1991. Dokumenty dyplomatyczne, red. W. B o r o d z i j, Warszawa 2006, s. 122.

8 „Przekazałem ministrowi spraw wewnętrznych moją decyzję, że tych uciekinierów nie będziemy odsyłać do NRD” - wspominał premier. Zob. T. Ma zo w i e ck i, op. cit., s. 140. Według Marka Prawdy, który w tym czasie organizował pomoc dla uchodźców z NRD z ramienia Komitetu Obywatelskiego Solidarność, Skubiszewski miał też zaproponować - na wypadek fiaska rozmów między NRD i RFN przetransportowanie uciekinierów do RFN drogą morską i powietrzną. Potwierdzenia tej informacji nie znalazłem w dokumentach MSZ. M. P raw da, Od wspólnoty losów do wspólnoty interesów - Polska i Niemcy w 1989 roku i dzisiaj [w:] Krzysztof Skubiszewski i dyplomacja czasów przełomu, red. M. M aruszkin, K. Szaładziński, Poznań 2016, s. 299.

${ }_{9}$ Polska wobec zjednoczenia..., s. 129.
} 
a jedynie o „osobach i grupach ludności polskiego lub niemieckiego pochodzenia”, ale obie strony deklarowały zapewnienie im szerszego dostępu do ojczystej kultury i języka. W tym zakresie, szczególnie istotnym dla strony niemieckiej, władze PRL zajmowały dotąd sztywne stanowisko. Dla rządu Mazowieckiego, przewidującego odejście od restrykcyjnego kursu wobec wszystkich mniejszości narodowych, ustępstwa na tym polu nie były szczególnie trudne, tym bardziej że strona niemiecka - reagując na proces demokratyzacji Polski, który w tym czasie czynił ją jeszcze pionierem w całym bloku radzieckim - złagodziła znacząco swoje stanowisko w sprawach finansowych. Te ostatnie zaś, z uwagi na katastrofalny stan budżetu państwa, miały dla nowego polskiego rządu zasadnicze znaczenie.

RFN była wówczas największym wierzycielem PRL, a poziom tego zadłużenia wynosił w końcu lat osiemdziesiątych minionego wieku 7,7 mld marek wobec państwa i kolejne 4,4 mld marek wobec banków prywatnych. Jesienią 1989 roku strona niemiecka zgodziła się między innymi na restrukturyzację części polskiego zadłużenia wobec RFN w wysokości 2,5 mld marek, pochodzącego z lat siedemdziesiątych. Część należności została umorzona $(760 \mathrm{mln})$, a $570 \mathrm{mln}$ marek zamieniono na złotówki, które miały posłużyć finansowaniu w Polsce różnych wspólnych projektów (m.in. wymianie młodzieżowej i kulturalnej). Dzięki tym środkom powstała Fundacja Współpracy Polsko-Niemieckiej, która w następnych latach miała odegrać bardzo istotną rolę w zbliżeniu obu narodów. RFN zgodziła się też na otwarcie gwarancji rządowych dla nowej akcji kredytowej w wysokości 3 mld marek, strona polska natomiast zrezygnowała $\mathrm{z}$ wcześniejszych postulatów, by nowe pożyczki zostały udzielone bez określania konkretnych celów, na jakie zostaną przeznaczone ${ }^{10}$. Całość porozumienia została ujęta w formie 78 punktów tzw. wspólnego oświadczenia, którego ostateczna wersja została ustalona dopiero podczas listopadowej wizyty kanclerza RFN w Polsce ${ }^{11}$.

Wydawało się wówczas, że droga do oczekiwanego przełomu w stosunkach polsko-niemieckich została otwarta i pozostaje jedynie wybrać symboliczne miejsce dla jego dokonania. Jego forma - Msza Święta z udziałem dwóch polityków otwarcie deklarujących swój katolicyzm - nie budziła wątpliwości, natomiast propozycja Bonn (skądinąd wymyślona przez opolskiego biskupa Alfonsa Nossola), by odbyła się ona na Górze Świętej Anny, a zatem w miejscu ściśle związanym z historią trzeciego powstania śląskiego, została odrzucona przez Mazowieckiego ${ }^{12}$. W tej sprawie premier obawiał się nie tylko protestów Jaruzelskiego i innych ludzi z komunistycznego aparatu władzy, ale i reakcji społecznych. ,Już nie pamiętam, kto wtedy - czy Mieczysław Pszon, czy ja, czy obaj równocześnie - wpadł na pomysł odwołania się

${ }^{10}$ Archiwum Prezydenta RP [dalej: APRP], sygn. 12/39, t. 2, List kanclerza RFN H. Kohla do premiera T. Mazowieckiego z 14 listopada 1989, s. 1-5. Zob. też K. Malinows ki, Polityka Republiki Federalnej Niemiec wobec Polski w latach 1982-1991, Poznań 1997, s. 164, 218-220, 230.

11 Jego pełny tekst zob. „Rzeczpospolita”, 16 listopada 1989; oraz L. Koćw in, Dekada przełomu. Stosunki polsko-niemieckie od czerwca 1989 do czerwca 1991. Dokumenty, materiały, komentarze, Wrocław 1993, s. 120-130.

12 D. Bingen, Polityka Republiki Bońskiej wobec Polski. Od Adenauera do Kohla 1949-1991, Kraków 1997, s. 245. Zob. też H. Kohl, Pragnąłem jedności Niemiec, Warszawa 1999, s. 69. 
do Krzyżowej, miejsca symbolizującego ruch oporu wobec Hitlera"'3. Wypada jednak zauważyć, że również $\mathrm{i}$ ta lokalizacja była $\mathrm{w}$ wymiarze symbolicznym korzystniejsza dla Bonn niż dla Warszawy. Koncentrowała bowiem uwagę na niewielkiej grupie Niemców, którzy mieli odwagę przeciwstawić się Hitlerowi, a nie na niemieckich zbrodniach wojennych, choć kanclerz miał w trakcie tej wizyty odwiedzić również Auschwitz. Pole manewru było jednak niewielkie, rząd Mazowieckiego bowiem, przejmując państwo w stanie faktycznego bankructwa, dramatycznie potrzebował zagranicznej pomocy finansowej, Kohl zaś mógł dalej spokojnie czekać na rozwój wydarzeń nad Wisłą.

„Polacy muszą mieć pewność, że granica na Odrze-Nysie to sprawa ostatecznie uregulowana” - usłyszał Kohl od Mazowieckiego podczas ich pierwszej bezpośredniej rozmowy, do jakiej doszło po przyjeździe kanclerza RFN do Warszawy 9 listopada 1989 roku. „Nastroje w RFN są sprzyjające - odpowiedział Kohl - 80-82\% ludności akceptuje granicę na Odrze i Nysie". Równocześnie jednak stwierdził kategorycznie: „Żaden rząd niemiecki nie może dziś uznać granicy Odra-Nysa w imieniu całych Niemiec, które dopiero powstaną w przyszłości"'14. Tego dnia wieczorem tysiące mieszkańców Berlina Wschodniego, zachęconych deklaracją władz NRD o natychmiastowym zniesieniu ograniczeń w podróżowaniu za granicę, wkroczyło do zachodniej części miasta i przystąpiło do niszczenia słynnego muru ${ }^{15}$. Przyszłość, o której mówił Kohl, okazała się znacznie bliższa, co już wkrótce postawiło polskiego premiera przed problemem reakcji na przytoczoną deklarację kanclerza. Niechęć Kohla do jednoznacznej deklaracji w sprawie granicy zachodniej Polski oficjalnie wynikała ze stanowiska prawnego, że RFN nie może się wypowiadać w imieniu przyszłego zjednoczonego państwa niemieckiego, a ostateczne uregulowanie tej kwestii powinno stanowić element składowy traktatu pokojowego ${ }^{16}$. W rzeczywistości jednak kanclerzowi chodziło - zwłaszcza w kontekście przypadających w 1990 roku kolejnych wyborów parlamentarnych - o tych blisko 20 proc. obywateli RFN, wciąż mających nadzieję na odwrócenie rezultatów wojny. „Kohl był świadom, że w sensie historycznym, ale także politycznym - między innymi z uwagi na stanowisko mocarstw - sprawa granicy jest przesądzona, ale jednocześnie chciał ograniczyć do minimum swoje koszty polityczne: nie stracić głosów wyborców związanych z prawym skrzydłem CDU/CSU i ziomkostwami" - oceniał po latach Janusz Reiter, który w 1990 roku został nowym ambasadorem Rzeczypospolitej w Bonn ${ }^{17}$.

10 listopada, pod wrażeniem nocnych wydarzeń w Berlinie, Kohl zdecydował się przerwać na jedną dobę swoją wizytę w Polsce. Przed wyjazdem spotkał się po raz kolejny z Mazowieckim, któremu powiedział: „Nie byłoby tego rozwoju [sytuacji] w NRD, gdyby najpierw nie było rozwoju refom w Polsce"18. Obiecał też wywar-

13 T. Mazowiecki, op. cit., s. 99.

14 Polska wobec zjednoczenia..., s. 160, 162.

15 Zob. T. Jaskułows ki, Pokojowa rewolucja w NRD w latach 1989-1990. Geneza - przebiegefekty, Wrocław 2007, s. 220-234.

${ }^{16}$ L. Jan icki, Podstawy prawne stosunków Polski ze zjednoczonymi Niemcami [w:] Wokół traktatów Polska-Niemcy, seria Biblioteka Przeglądu Zachodniego, z. 16, Poznań 1992, s. 17.

17 J. R e it e r, Jak definiujemy swą rolę w Europie [w:] Krzysztof Skubiszewski..., s. 314.

18 Polska wobec zjednoczenia..., s. 163. 
cie nacisku na Międzynarodowy Fundusz Walutowy w celu przyspieszenia umowy z Polską oraz deklarował, że jeśli USA zwiększą swój udział w tworzonym wówczas funduszu mającym ułatwić stabilizację kursu złotówki z 200 do $250 \mathrm{mln}$ USD, to również RFN zwiększy do tego poziomu swój udział. W tej rozmowie nie pojawił się jeszcze problem zjednoczenia Niemiec, ale inaczej było już podczas spotkania, jakie odbyli tego samego dnia szefowie dyplomacji obu krajów. „Uznajemy prawo wszystkich narodów do samostanowienia, a więc także Niemców" - stwierdził Skubiszewski, natychmiast jednak dodał, że „problem jedności niemieckiej” jest uzależniony do postawy mocarstw tworzących koalicję antyhitlerowską oraz sąsiadów Niemiec. Swój wywód szef polskiego MSZ zakończył jednoznaczną deklaracją: „Zjednoczenie Niemiec nie jest $\mathrm{w}$ tej chwili kwestią aktualną, nie stoi na porządku dnia i może być traktowane jako zagadnienie odległej przyszłości”. Hans-Dietrich Genscher zareagował na to dłuższym wywodem na temat przezwyciężania skutków dyktatury nazistowskiej w RFN i próbował przekonać Skubiszewskiego, że jego kraj „wyraźnie rozróżnia między «zjednoczeniem» [...] a jednością, do której obowiązany jest dążyć zgodnie z konstytucyjnym nakazem. W żadnym wypadku nie należy liczyć się z tym, że jest to dążenie do restauracji poprzedniego państwa niemieckiego" "19.

Upadek muru berlińskiego nie przesądzał jeszcze ani kwestii zjednoczenia, ani tym bardziej tempa tego procesu, ale dla obu stron było jasne, że $\mathrm{z}$ tą chwilą we wzajemnych stosunkach, zdominowanych dotąd przez kwestie związane z zadłużeniem Polski w RFN, zadośćuczynieniem dla polskich ofiar III Rzeszy oraz praw mniejszości narodowych w obu krajach, pojawił się nowy fundamentalny problem. Tym bardziej że zjednoczenie Niemiec bardzo szybko przestało być „odległą przyszłością", o której mówił Skubiszewski. Kohl - po jednodniowym pobycie w Berlinie, gdzie wygłosił ostrożne przemówienie, powrócił do Polski, by 12 listopada wziąć udział w Mszy Świętej w Krzyżowej, której kulminacyjnym momentem był słynny gest pojednania szefów obu rządów - w trakcie kolejnej rozmowy z Mazowieckim był wyjątkowo powściągliwy. Wiedział bowiem, że kierunek rozwoju sytuacji w NRD nie jest przesądzony (w pierwszych dniach po 9 listopada obawiano się użycia siły przez pogrążającą się w chaosie ekipę Egona Krenza), nie było też jeszcze całkowicie jasne stanowisko USA, bez którego wsparcia otwarte podejmowanie sprawy zjednoczenia było nader ryzykowne. $Z$ kolei Mazowiecki ograniczył się jedynie do wyrażenia nadziei, że kanclerz rozumie znaczenie kwestii granic w kontekście ewentualnego zjednoczenia Niemiec. Kohl odparł na to, że „sprawa granicy jest może jeszcze tematem wewnętrzno-politycznym w RFN, a nie między Polską a Niemcami” i poprosił, aby „nie rozgrywać tej sprawy propagandowo na wspólnej konferencji prasowej" ${ }^{20}$. Polski premier zastosował się do prośby niemieckiego gościa, ale już wkrótce miało się okazać, że nie wierzy w deklarację kanclerza w sprawie zachodniej granicy Polski, choć punkt 4 ,wspólnego oświadczenia" podpisanego przez obu polityków na zakończenie wizyty stwierdzał, że układ między PRL a RFN z 7 grudnia 1970 roku uważają za „trwały fundament ich stosunków”, a punkt 6 zawierał zobowiązanie obu stron do „wypełniania tego

\footnotetext{
19 Ibidem, s. 168.

${ }^{20}$ Ibidem, s. 169.
} 
układu w przyszłości zgodnie z jego duchem i literą” oraz uznawania go „za podstawę pełnej normalizacji i wszechstronnego rozwoju stosunków wzajemnych"²1.

Minister Skubiszewski, komentując 20 listopada rezultaty wizyty Kohla na posiedzeniu Rady Ministrów, stwierdził, że zawarta we wspólnym oświadczeniu ,klauzula co do granicy nie jest taka, jak byśmy sobie życzyli, ale to w końcu może nie jest aż tak istotne". Zaskakująca, w świetle późniejszych działań szefa polskiej dyplomacji, była też jego sugestia ,aby może tak wiele wciąż o granicy nie dyskutować, bo kto tak wciąż wiele o tym mówi, to znaczy, że może i on sam ma tutaj jakieś wątpliwości. Tymczasem my żadnych wątpliwości nie mamy i co więcej - Europa tych wątpliwości nie ma. Te różne wątpliwości są zgłaszane tylko przez pewne grupy w Niemczech, nie przez większość". Generalna ocena szefa MSZ była jednak bardzo optymistyczna i nawet $\mathrm{w}$ sprawach, w których strona niemiecka ewidentnie grała na zwłokę, starał się dostrzegać pozytywy. Tak było na przykład w kwestii związanej z zadośćuczynieniem dla polskich ofiar wojny. Przyznając, że w trakcie rozmów „nie uregulowano sprawy roszczeń osób poszkodowanych przez III Rzeszę, zwłaszcza robotników przymusowych", Skubiszewski przekonywał członków rządu, że „i tutaj zaznaczył się pewien postęp, bo dotąd Niemcy nie chcieli w ogóle na ten temat rozmawiać, a tym razem i minister Genscher, i kanclerz Kohl rozmawiali na ten temat i mówili, że to jest sprawa do dalszych rozmów w przyszłości”. Sam premier ograniczył się wówczas do stwierdzenia, że ,zgadza się z tymi ocenami pana ministra Skubiszewskiego, z wszystkimi tutaj wypowiedzianymi" i ocenił, że ,W sumie dość dużo udało się załatwić” ${ }^{2}$.

W świetle tych ocen, sformułowanych zaledwie kilka dni po wyjeździe Kohla, można przyjąć, że zarówno Skubiszewski, jak i Mazowiecki nie uważali wówczas upadku muru berlińskiego za zwiastun szybkiego zjednoczenia państw niemieckich, ale co najwyżej za impuls uruchamiający długotrwały proces polityczny, na końcu którego pojawiłaby się sprawa granicy. W tym miejscu wypada zadać pytanie, czy premier Tadeusz Mazowiecki był wówczas zwolennikiem zjednoczenia Niemiec. Następującej odpowiedzi na to pytanie udzielił Krzysztof Skubiszewski: „Ja nie miałem co do zjednoczenia wątpliwości, ale inni ludzie mieli, wraz z Mazowieckim. Premier był pełen wątpliwości, zwłaszcza z uwagi na granicę zachodnią"’33.

Momentem, w którym te wątpliwości uległy gwałtownemu spotęgowaniu, stało się przemówienie, jakie Kohl wygłosił w Bundestagu w dwa tygodnie po wizycie w Polsce. Przedstawił w nim swój dziesięciopunktowy program ,przezwyciężenia podziału Niemiec i Europy"24, w którym jednak zabrakło stwierdzenia o uznaniu

21 „Rzeczpospolita”, 16 listopada 1989.

22 Archiwum Kancelarii Prezesa Rady Ministrów [dalej: AKPRM], bez sygn., Zapis przebiegu obrad posiedzenia Rady Ministrów z 20 listopada 1989 r., s. 8, 9, 12.

${ }^{23}$ P. Sk u b is zew s ki, Rozmowa z moim bratem [w:] Krzysztof Skubiszewski..., s. 40. Warto dodać, że z badań socjologicznych przeprowadzonych na początku 1990 r. wynikało, że ok. 60\% Polaków było przeciwnych zjednoczeniu Niemiec. Zob. M. S tolarczyk, Niektóre problemy w stosunkach polsko-niemieckich $w$ pierwszej połowie lat dziewięćdziesiątych [w:] Stosunki polsko-niemieckie $w$ okresie przemian ustrojowych $w$ Polsce, red. P. Dobrow ols ki, Katowice 1997, s. 9.

${ }_{24}$ Tekst przemówienia H. Kohla, http://www.chronik-der-mauer.de/material/180402/rede-von-bundeskanzler-helmut-kohl-im-bundestag-10-punkte-programm-28-november-1989 [dostęp: 26.06.2017]. 
trwałości polskiej granicy zachodniej. „To mnie postawiło do pionu” - wspominał w jednym z wywiadów Mazowiecki i dodawał: „Niemcy szli pełną parą do zjednoczenia. Uważałem, że nie wolno nam tego momentu przegapić i trzeba uregulować sprawę naszej zachodniej granicy"25. Jako pierwszy publicznie na plan Kohla zareagował jednak minister Skubiszewski. Na początku grudnia opublikował artykuł, w którym wprost napisał, że zasadniczym brakiem planu Kohla ,jest przemilczenie sprawy granic z sąsiadami obu państw niemieckich, w szczególności z Polską". Równocześnie jednak przekonywał: „Ani jutro, ani pojutrze zjednoczone Niemcy nie powstaną. Pod tym względem obawy i niepokoje niekiedy dające o sobie znać u nas nie są uzasadnione, choć czujność jest wskazana"26.

Zarówno szef polskiej dyplomacji, jak i premier Mazowiecki żywili przekonanie, że proces odbudowy jedności Niemiec będzie rozciągnięty na co najmniej kilka lat aż do początków 1990 roku. Szefa polskiego rządu utwierdzały w tym wypowiedzi sekretarza generalnego KPZR Michaiła Gorbaczowa, jakie usłyszał 4 grudnia 1989 roku podczas spotkania przywódców państw Układu Warszawskiego w Moskwie. W jego trakcie Gorbaczow następująco zrelacjonował przebieg swojej rozmowy, odbytej kilka dni wcześniej u wybrzeży Malty z prezydentem USA George'em Bushem:

Amerykanie potwierdzają zasadę nienaruszalności granic i istnienie dwóch państw niemieckich. Znaczną rolę odgrywa dziś czynnik emocjonalny w samych Niemczech, ale żadnego przyspieszenia procesu jednoczenia Niemiec nie będzie. Kohl niesłusznie powiedział, że omawialiśmy projekt konfederacji. Nie omawialiśmy, bo co to znaczy konfederacja? Wspólna polityka zagraniczna, wojskowa itp.? Nie, nie teraz. Problem niemiecki to problem światowy. Wydaje się, że Kohl spekuluje hasłem konfederacji, chcąc się przypodobać swoim wyborcom ${ }^{27}$.

Niemal jednak dokładnie w tym samym czasie, gdy Gorbaczow przekonywał przywódców trzeszczącego w szwach bloku radzieckiego, że Bush potwierdził zasadę utrzymania dwóch państw niemieckich, ten ostatni rozmawiał z Kohlem w Brukseli, gdzie przybył, by poinformować przywódców państw NATO o przebiegu szczytu u wybrzeży Malty. „Dałem mu do zrozumienia - wspominał prezydent USA - że nie będę sprzeciwiał się reunifikacji [Niemiec] i tym samym w pewnym

25 T. Mazowiecki, op. cit., s. 141, 149.

26 „Rzeczpospolita”, 9-10 grudnia 1989.

27 Zmierzch dyktatury. Polska lat 1986-1989 w świetle dokumentów, t. II (czerwiec-grudzień 1989), red. A. Dudek, Warszawa 2010, s. 484. Informacje utrzymane w podobnym tonie nadsyłała też do Warszawy ambasada polska w Moskwie, informując np., że podczas spotkania 5 grudnia 1989 r. z Genscherem Gorbaczow „krytycznie ocenił 10-punktowy plan Kohla, podkreślając, że przeczy on treści i duchowi układów, jakie RFN zawarła z ZSRR i innymi K[rajami] S[ocjalistycznymi], zmierza do rewizji powojennego układu polityczno-terytorialnego w Europie, osłabia proces KBWE i jest praktycznie wymierzony przeciwko NRD". Archiwum Ministerstwa Spraw Zagranicznych, sygn. 24/91, w. 14, Szyfrogram 0-3106/IV z Moskwy z 6 grudnia 1989 r. O tym, że polska ambasada była dobrze poinformowana o ówczesnym stanowisku Gorbaczowa, przekonuje zapis rozmowy Gorbaczow-Genscher z 5 grudnia 1989 r. Zob. Михаил Горбачев и германский вопрос. Сборник документов 1986-1991, red. А. Галкин, А. Черн я ев, Москва 2006, s. 273-284. 
sensie zapaliłem dla niego zielone światło"28. Z perspektywy Bonn był to istotnie moment decydujący, ponieważ - wobec nieskrywanej niechęci władz Wielkiej Brytanii, Francji oraz ZSRR wobec wizji szybkiego zjednoczenia Niemiec - poparcie Waszyngtonu okazało się rozstrzygające dla powodzenia tej inicjatywy. Dla Amerykanów, jak napisał Bush w swoich wspomnieniach, oczywiste były cztery warunki zjednoczenia, jakie sformułowano w Departamencie Stanu: 1) respektowanie zasady samostanowienia narodów; 2) pozostanie Niemiec w NATO i Wspólnocie Europejskiej; 3) dokonanie tego w sposób „stopniowy i pokojowy”; 4), ,respektowanie zasad zawartych w helsińskim akcie końcowym [KBWE] dotyczących nienaruszalności istniejących granic" ${ }^{29}$.

Wydarzenia, do jakich doszło na przełomie 1989 i 1990 roku w NRD ${ }^{30}$, sprawiły, że perspektywa zjednoczenia stała się coraz wyraźniejsza. Równocześnie Kohl rozpoczął prowadzoną równolegle w Moskwie, Londynie i Paryżu akcję, której celem było przekonanie mocarstw koalicji antyhitlerowskiej do wyrażenia zgody na zjednoczenie, w czym istotnym argumentem było stanowisko zajęte przez Busha. Podczas pobytu w Paryżu 17 stycznia 1990 roku poruszył w przemówieniu kwestię granic, mówiąc, że „Polacy muszą mieć pewność, iż żyją w bezpiecznych granicach". Nawiązał jednak w tym kontekście nie do gwarancji prawnotraktatowych, ale do wysiedlenia ludności niemieckiej z ziem utraconych po II wojnie światowej. „Nikt nie chce drugiego wypędzenia po potwornościach wypędzenia, których Niemcy doświadczyli na sobie. Nikt nie chce zatem łączyć zjednoczenia z przesunięciem istniejących granic - granic, które w przyszłej Europie wolności będą tracić na znaczeniu" "31 - stwierdził kanclerz, ale taka retoryka nie uspokajała polskiego rządu, w którym coraz wyraźniej zdawano sobie sprawę, że proces zmian zachodzących na zachód od Polski gwałtownie przyspiesza.

„Zjednoczenie Niemiec wydaje się przesądzone” - ocenił w połowie lutego 1990 roku Mazowiecki, rozmawiając w Londynie z premier Wielkiej Brytanii Margaret Thatcher. W tym kontekście za sprawę fundamentalną uznał potwierdzenie nienaruszalności granic i wyraził obawę: „Czy w tej przyszłej Europie czynnik niemiecki nie będzie dominujący, czy nie stworzy innej równowagi europejskiej?” Thatcher należała do tej grupy zachodnioeuropejskich polityków, którzy podzielali obawy Mazowieckiego ${ }^{32}$, i dlatego bez ogródek odpowiedziała:

Ja obawiam się Niemiec. [...] jestem patriotką i robię, co mogę, by ten proces opóźnić. [...] Wszystkie wątpliwości muszą być rozwiązane przed zjednoczeniem.

${ }^{28}$ G. Bus h, B. Sc ow croft, Świat przekształcony, Warszawa 2000, s. 207-208.

29 Ibidem, s. 205.

${ }^{30}$ Chodzi tu zwłaszcza o rozpad partii komunistycznej SED, wtargnięcie tysięcy demonstrantów do głównej siedziby Stasi w Berlinie (15 stycznia 1990), konflikty w łonie nowego rządu, którym kierował Hans Modrow, a przede wszystkim o nieustanną migrację obywateli NRD na teren RFN, która w styczniu 1990 r. osiągnęła poziom dwóch tysięcy osób dziennie. Zob. A. Gubrynowicz, op. cit., s. 154; T. J a s kułows ki, op. cit., s. 297-340.

31 Cyt. za: K. Malinows ki, op. cit. s. 244.

${ }^{32} \mathrm{Na}$ temat stosunku brytyjskiej premier do zjednoczenia Niemiec zob. M. That che r, Moje lata na Downing Street, Warszawa 2012, s. 816-825. 
Neutralność Niemiec jest wykluczona. Zostaną tam wojska USA, także brytyjskie. Gorbaczow powinien zostawić swoje wojska w NRD. Jednym z celów Helsinek II powinna być gwarancja dla polskich granic.

Przez „Helsinki II” brytyjska premier rozumiała porozumienie między władzami NRD, RFN i czterech mocarstw koalicji antyhitlerowskiej, które przybrało ostatecznie kształt konferencji 2+4. Dostrzegając w Thatcher sojusznika, Mazowiecki zapytał ją wprost, czy Wielka Brytania ,poparłaby Polskę, gdyby wystąpiła o podpisanie układu pokojowego? Zjednoczenie Niemiec jest ostatnim momentem, który można w tym celu wykorzystać". Thatcher, upewniwszy się, że polskie żądania związane z układem pokojowym dotyczyłyby jedynie sprawy granic, a nie odszkodowań, odpowiedziała twierdząco, co wywołało następujący komentarz Mazowieckiego: „Najlepiej - traktat pokojowy - jeśli to niemożliwe, to Helsinki II, ale mające charakter traktatowy".

Podczas tej rozmowy premier brytyjskiego rządu interesowała się również kwestią obecności wojsk radzieckich w Polsce. Mazowiecki odparł, że w tej sprawie sytuacja Polski jest inna niż Czechosłowacji oraz Węgier, ponieważ

[...] wojska, które są u nas, są logistycznym zapleczem wojsk radzieckich stacjonujących w NRD. Chcemy, aby w ramach rozwoju sytuacji siły te się zmniejszały. [...] Zmniejszenie to jedno - wtrąciła Thatcher - a wycofanie, to drugie.

[...] ale za wcześnie na wycofanie - dokończył premier T. Mazowiecki. Jeśliby do głosu doszli twardogłowi - powiedziała premier M. Thatcher - to zmieniłoby sytuację. Ale myślę, że Gorbaczow przejdzie przez trudności.

[...] Mam też taką nadzieję - powiedział premier T. Mazowiecki - [...] Będzie miał trudności, ale zakładam, że się utrzyma, że zaszły tam już nieodwracalne procesy ${ }^{33}$.

W ten sposób brytyjska premier delikatnie wskazała na największe ryzyko wiążące się z przyjętą wówczas przez polski rząd taktyką, która zakładała niepodejmowanie sprawy obecności wojsk radzieckich w Polsce do czasu wyjaśnienia sprawy granicy zachodniej ${ }^{34}$. Ryzyko polegające na możliwości gwałtownego zwrotu w polityce ZSRR. Mazowiecki był jednak przekonany, że linia polityczna Kremla nie zmieni się przynajmniej do czasu uregulowania kwestii niemieckiej, i to właśnie na przekonywaniu czterech mocarstw do konieczności zagwarantowania polskich granic jeszcze przed zjednoczeniem Niemiec postanowił skoncentrować działalność polskiej dyplomacji w pierwszej połowie 1990 roku. Było to o tyle zaskakujące, że z jego rozmowy z Thatcher wynikało, że zdaje sobie sprawę z szybkiej ewolucji stanowiska Gorbaczowa w sprawie jedności Niemiec. Przyznawał bowiem, że o ile podczas swej podróży do Moskwy w końcu listopada 1989 roku miał wrażenie, że radziecki przywódca wyklucza takie rozwiązanie, o tyle po upływie zaledwie trzech miesięcy sytuacja uległa zmianie: „W listopadzie to był całkowity mur. Obecnie sądzę, że Gorbaczow może się zgodzić na zjednoczenie, ale nie

33 Polska wobec zjednoczenia..., s. 193-196.

${ }^{34}$ Szerzej na ten temat zob. A. Dudek, Ewolucja stanowiska rzadu Tadeusza Mazowieckiego w sprawie obecności Polski w Układzie Warszawskim oraz stacjonowania na jej terytorium wojsk radzieckich, „Dzieje Najnowsze” 2015, nr 4, s. 162-175. 
na zachwianie równowagi militarnej”35. Ryzyko to Mazowiecki postrzegał jednokierunkowo, a zatem w postaci jego obalenia oraz dojścia do władzy na Kremlu sił przeciwnych zmianom w radzieckiej polityce wewnętrznej i zagranicznej zachodzącym od kilku lat. Polski premier zdawał się natomiast kompletnie nie brać pod uwagę dalszej ewolucji Gorbaczowa, która - za sprawą potężnych środków finansowych uruchomionych przez RFN na rzecz ZSRR - kilka miesięcy później doprowadziła go do wyrażenia zgody już nie tylko na błyskawiczne zjednoczenie Niemiec i wycofanie wojsk radzieckich z obszaru likwidowanej NRD, ale i akceptację przynależności tego państwa do NATO. Oparcie zaś granicy NATO na Odrze stawiało - z punktu widzenia Moskwy - kwestię obecności wojsk radzieckich w Polsce zupełnie inaczej, niż to było jeszcze w lutym 1990 roku, gdy władze ZSRR same złożyły propozycję rozpoczęcia rozmów w tej sprawie ${ }^{36}$.

Rząd Mazowieckiego nie miał też wówczas jasnego stanowiska w sprawie obecności zjednoczonych Niemiec w NATO, czemu dał wyraz w połowie marca minister Skubiszewski, mówiąc do ambasadora USA w Warszawie Johna Davisa, że „Polska nie wypracowała ostatecznego stanowiska $\mathrm{w}$ tej kwestii. Do pewnego stopnia i na zasadzie wzajemności bierzemy też pod uwagę interes ZSRR" ${ }^{37}$. Nietrudno się domyśleć, jak te słowa mogły zostać odebrane w Waszyngtonie, który w tym czasie $\mathrm{z}$ całą mocą zaangażował się w poparcie dla wizji Kohla.

Zabiegi o udział w negocjacjach dotyczących zjednoczenia Niemiec stały się głównym celem działań ministra Skubiszewskiego na konferencji państw Układu Warszawskiego i NATO w Ottawie (12-13 lutego 1990), gdzie przy okazji podpisania traktatu o otwartych przestworzach rozmawiano głównie o problemie zjednoczenia Niemiec. Szef polskiej dyplomacji spotkał się wówczas między innymi $\mathrm{z}$ amerykańskim sekretarzem stanu Jamesem Bakerem. Co jednak interesujące, w przeciwieństwie do Mazowieckiego stwierdził, że choć Polska jest gotowa poprzeć zawarcie traktatu pokojowego z Niemcami, „to 50 lat po wojnie niewiele już zostało do uregulowania w ramach traktatu" i dlatego formułuje postulat wydania „oświadczenia parlamentów i rządów RFN i NRD oraz sprawę ujęcia w formie traktatowej pewnych zasad Aktu końcowego KBWE, które gwarantowałyby między innymi sprawę granic". Na pytanie Bakera o obecność wojsk radzieckich w Polsce Skubiszewski odpowiedział niemal identycznie jak Mazowiecki w rozmowie z Thatcher, podkreślając, że ma ona „znaczenie strategiczne” i nie można jej zestawiać z rolą, jaką żołnierze radzieccy odgrywają w Czechosłowacji i na Węgrzech. Zapytany zaś o możliwość rozwiązania Układu Warszawskiego odparł zdawkowo, że ,zmienia on charakter i traci swoje znaczenie”. Amerykański sekretarz stanu ograniczył się do zapewnienia, że ,jest optymistą i że znajdą się rozwiązania gwarantujące bezpieczeństwo i stabilizację”. Dodał też, że USA „popierają sugestie Kohla i Genschera i zdają sobie sprawę, że nie mogą to być rozwiązania stanowiące groźbę dla Wschodu"38.

\footnotetext{
35 Polska wobec zjednoczenia..., s. 195.

36 P. Malew ic z, Polska polityka wschodnia w latach 1989-1991, Toruń 2008, s. 139.

37 Polska wobec zjednoczenia..., s. 231.

38 Ibidem, s. 198-199.
} 
W trakcie rozmów w Ottawie Skubiszewskiemu udało się uzupełnić oficjalny dokument przyjęty tam przez ministrów spraw zagranicznych (a dotyczący rozpoczęcia rozmów na temat zjednoczenia Niemiec w formule 2+4) o zdanie stwierdzające, że tematem obrad powinien stać się również ,problem bezpieczeństwa państw sąsiednich"39. Odwołując się później do tego właśnie zdania, rząd Mazowieckiego zaczął się następnie domagać udziału przedstawiciela Polski w sesji konferencji 2+4 dotyczącej spraw granicznych.

Szef polskiego MSZ odbył w Ottawie rozmowę z ministrem spraw zagranicznych ZSRR Eduardem Szewardnadze. 12 lutego, w dniu ich spotkania, moskiewska „Prawda” opublikowała Oświadczenie Rzadu ZSRR w sprawie gotowości przeprowadzenia rozmów dotyczacych wojsk radzieckich $w$ Polsce, w którym przypomniano, że ZSRR rozpoczął już negocjacje z Czechosłowacją oraz Węgrami, a,,wszystkie okoliczności wskazują na to, że [...] żołnierze i oficerowie radzieccy powrócą z tych państw do domu w możliwie najkrótszym terminie". W tym kontekście w oświadczeniu napisano: „Jeżeli rząd Rzeczypospolitej Polskiej wyrazi stosowne pragnienie, to moglibyśmy omówić również z jego przedstawicielami problem wojsk radzieckich w tym kraju" "40. Komentując tę deklarację, Skubiszewski oświadczył Szewardnadze: „Na dzień dzisiejszy rząd Polski wypowiada się za redukcją wojsk radzieckich i uregulowaniem finansowym. Sprawa wycofania będzie omawiana później, także w związku z rozmowami wiedeńskimi ${ }^{41}$ i sytuacją w Niemczech, gdy Polska powróci do postulatu całkowitego wycofania wojsk radzieckich". Odpowiadając na to, Szewardnadze ,potwierdził gotowość w każdej chwili do rozmów na ten temat” i dodał: „Ważne jest, aby naród polski wiedział, że Związek Radziecki nie ma żadnych złych zamiarów przeciwko Polsce". Zapewnił też, że w sprawach dotyczących zjednoczenia Niemiec ZSRR chce być „,bliskim partnerem Polski”42.

Cztery dni po tym spotkaniu Mazowiecki zatelefonował do Gorbaczowa, by - powołując się na swoją rozmowę z Thatcher - przedstawić mu swoje postulaty. Po pierwsze domagał się, aby władze RFN i NRD parafowały projekt traktatu granicznego, który następnie zostałby podpisany przez rząd utworzony po zjednoczeniu. Po drugie postulował, by w programie konferencji $2+4$ została wyodrębniona część dotycząca bezpieczeństwa sąsiadów Niemiec, i by mogli w niej uczestniczyć przedstawiciele Polski. Poprosił, aby sam Gorbaczow lub ktoś inny z władz ZSRR w publicznym wystąpieniu poparł te polskie żądania. Radziecki przywódca zgodził się na to i przyznał,

39 W.M. Góralski, Stosunki polityczne Polska-Niemcy [w:] Polacy i Niemcy na drodze do partnerskiego sąsiedztwa. Próba bilansu dziesięciolecia 1989-1998, red. D. B ing en, K. Malinow ski, Poznań 2000, s. 276.

${ }^{40}$ Cyt. za: J. Strzelczyk, Ucieczka ze wschodu. Rosja w polskiej polityce 1989-1993, Warszawa 2002, s. 68.

${ }^{41}$ Chodziło o prowadzone w Wiedniu rokowania między państwami NATO i Układu Warszawskiego w sprawie ograniczenia zbrojeń konwencjonalnych.

42 Polska wobec zjednoczenia..., s. 200-202. W Ottawie udało się Skubiszewskiemu włączyć do oświadczenia ministrów spraw zagranicznych dwóch państw niemieckich oraz czterech mocarstw zdanie o konieczności uwzględnienia w procesie zjednoczenia Niemiec bezpieczeństwa państw z nimi sąsiadujących. Zob. J. B a r c z, Udzial Polski w konferencji 2+4. Aspekty prawne i proceduralne, Warszawa 1994 , s. 28-30. 
że podczas rozmów prowadzonych z kanclerzem RFN „Kohl wymigiwał się, «manewrował» w sprawie granic”, co skłoniło Gorbaczowa do deklaracji: „Punkt ten jest u nas pod szczególną kontrolą! I żadnych tu kompromisów nie może być!’ Dodał też, że dla ZSRR ,nie do przyjęcia jest, jeśli w rezultacie zjednoczenia NATO zyska przewagę" i w tym kontekście pytał kanclerza, dlaczego Indie, Chiny urządza status państw niezaangażowanch i dlaczego jego nie może to satysfakcjonować. Swoją wypowiedź zakończył mocną deklaracją: „Panie premierze, pan może liczyć, że we wszystkich tych sprawach będziemy razem z wami. Żadnych ustępstw nie będzie!"43 Znamienne, że w trakcie całej rozmowy Mazowiecki ani słowem nie wspomniał o propozycji Kremla rozpoczęcia negocjacji w sprawie wojsk radzieckich z Polski.

Na konferencji prasowej 21 lutego 1990 roku Tadeusz Mazowiecki ogłosił dwa żądania Polski związane ze zjednoczeniem Niemiec, które przedstawił wcześniej Gorbaczowowi. Poinformował też, że skierował do przywódców czterech mocarstw listy zawierające te propozycje ${ }^{44}$. Odpowiadając na pytania dziennikarzy, stwierdził, że „Wielka Brytania ustosunkowała się pozytywnie do polskiej propozycji. Podobnie Związek Radziecki. Nie jest znana dotychczas odpowiedź Francji, a stanowisko Stanów Zjednoczonych nie jest być może jeszcze ostateczne". Dał też do zrozumienia, że do czasu rozwiązania „problemu niemieckiego" wojska radzieckie powinny pozostać w Polsce, choć „w dalszej perspektywie wojska te oczywiście opuszczą nasz kraj”45.

Dwa dni po tej konferencji Mazowiecki zdecydował się wieczorem zadzwonić do Kohla (wcześniej rozmawiał też na ten temat z premierem NRD Hansem Modro$w^{4}{ }^{46}$ ), by dowiedzieć się, jaka jest reakcja kanclerza. Odnosząc się do pierwszego postulatu, Kohl zasłonił się stanowiskiem niemieckiego sądu konstytucyjnego:

Nie mogę sobie pozwolić w obecnej sytuacji na spór z sądem w Karlsruhe. Rozumie pan? Dlatego to, co robię, muszę robić w taki sposób, żeby nie było podważalne. A czas i rozstrzygnięcie, którego pan oczekuje i które nadejdzie, jest rozstrzygnięciem, które nadejdzie w chwili zjednoczenia. Będzie miało formę traktatową, która będzie panu odpowiadać.

${ }^{43}$ APRP, sygn. 44/34, Rozmowa T. Mazowieckiego z M. Gorbaczowem - 16.02 .1990 r., b.p.

${ }^{44}$ W czterostronicowym liście o identycznej treści Mazowiecki pisał: „Przy działaniu w dobrej wierze nie może więc być przeszkody, aby u progu procesu zjednoczenia w formie traktatowej potwierdzić granicę polsko-niemiecką w jej obecnym przebiegu”. Domagając się zaś udziału „we wczesnym stadium" konferencji 2+4, argumentował, że wykluczenie z niej któregokolwiek z zainteresowanych udziałem sąsiadów Niemiec „,równałoby się powrotowi do formuły jałtańskiej z 1945 r. Byłoby bowiem dyskutowaniem i decydowaniem przez jedne państwa o żywotnych interesach innych państw bez udziału tych ostatnich". APRP, sygn. 44/37, List T. Mazowieckiego do G.H. Busha z 20 lutego 1990 r., k. 1-4.

45 „Rzeczpospolita”, 22 lutego 1990.

${ }^{46}$ Modrow odwiedził Warszawę w połowie lutego 1990. Podczas spotkania z Jaruzelskim i Skubiszewskim zadeklarował poparcie dla polskich postulatów i poinformował: „,...] na konferencji prasowej w Bonn zastosowałem pewien «trick». Powiedziałem mianowicie, że zrozumiałem, iż kanclerz Kohl zgadza się na potwierdzenie trwałości granicy na Odrze i Nysie. Kohl się od tego natychmiast zdystansował i przeszedł na swoje stare pozycje, mówiąc, że może to dopiero zrobić rząd zjednoczonych Niemiec. Ja powtórzyłem, że my uznaliśmy już tę granicę w 1950 roku”. APRP, sygn. 44/34, Zapis rozmowy Prezydenta RP Wojciecha Jaruzelskiego z Premierem NRD Hansem Modrowem. Belweder, 16 lutego 1990, k. 3. 
Mazowiecki próbował jeszcze nakłonić kanclerza do złożenia publicznej deklaracji w tej sprawie, ale ten zaoferował mu jedynie kolejne spotkanie. Także i w przypadku drugiego postulatu polskiego premiera Kohl był otwarcie niechętny, mówiąc, że do udziału w konferencji $2+4$ aspiruje wiele krajów: „Nie wezmę udziału w rokowaniach, na których Niemcy będą siedzieć, a pokojowy kongres będzie ich sądzić". Starając się przekonać kanclerza, Mazowiecki stwierdził: „Niech pan zrozumie, że to nie może być powtórzenie Jałty dla nas”. Usłyszał w odpowiedzi: „Porównanie z Jałtą nie jest porównaniem, które nie poruszyłoby Niemca. Jałta to nasz los, bo nastąpił tam podział. [...] To co stało się w Jałcie, dotyczy tak samo was, jak i nas"47. Relacjonując przebieg tej rozmowy na posiedzeniu rządu 26 lutego, Mazowiecki powiedział: „Nie jest to rozmowa z tamtej strony zamykająca, ale nie jest też rozmowa, powiedzmy, specjalnie zachęcająca" ${ }^{\text {"4 }}$. Także Kohl dał wyraz swojemu rozczarowaniu, mówiąc 12 marca do grupy dziennikarzy, z którymi spotkał się w Bonn: „Nie powinno być również tak, że o propozycji premiera Mazowieckiego i jego postulacie udziału w rozmowach $2+4$ dowiaduję się z zewnątrz i w nocy". Podczas tego spotkania Kohl oświadczył też: „Ponieważ znam Polaków, muszę być ostrożny i nie mogę zostawić sprawy reparacji na stole. [...] traktat graniczny z Polską będzie miał charakter uregulowania pokojowego, załatwiającego definitywnie sprawę granicy, to nie możemy jednocześnie zostawiać otwartej kwestii reparacji”"49. W ten sposób kanclerz odsłonił jeszcze jeden motyw swojego stanowiska w sprawie granicy na Odrze: była nim obawa przed podjęciem przez stronę polską kwestii reparacji wojennych. 18 marca Kohl wydał oświadczenie, w którym przyszłe porozumienie graniczne uzależnił od rezygnacji Polski z reparacji wojennych i traktatowego zagwarantowania praw mniejszości niemieckiej. Szczególnie ten ostatni warunek, z uwagi na swój historyczny kontekst, zbulwersował stronę polską.

Nieustępliwe stanowisko Kohla wywołało też kontrowersje w koalicyjnym rządzie RFN, ponieważ Genscher, reprezentujący w nim jako wicekanclerz i minister spraw zagranicznych liberalną FDP, opowiadał się za bardziej elastyczną polityką wobec Warszawy. Spór między obu politykami rozwiązano 8 marca, gdy Bundestag - zgodnie z pomysłem Genschera, do którego ostatecznie przychylił się kanclerz - uchwalił rezolucję, w której zapowiadał, że po przeprowadzeniu wyborów do Izby Ludowej NRD oba parlamenty wydadzą deklarację dotyczącą ,nienaruszalności granic jako niezbywalnej podstawy pokojowego współżycia w Europie”. Najistotniejsze zdanie tej rezolucji (przyjętej przy pięciu wstrzymujących się głosach parlamentarzystów CDU/CSU) brzmiało następująco: „Naród polski powinien wiedzieć, że jego prawo do życia w bezpiecznych granicach nie będzie ani teraz, ani w przyszłości kwestionowane przez Niemców"s0. Był to krok w dobrym kierunku, ale nie zadowolił polskiego rządu, rozwijającego dyplomatyczną ofensywę, której

47 T. Mazowiecki, op. cit., s. 118-120.

48 AKPRM, bez sygn., Zapis przebiegu obrad posiedzenia Rady Ministrów z 26 lutego 1990 r., k. 111.

49 Polska wobec zjednoczenia..., s. 227. W trakcie tego spotkania Kohl zapytany przez jednego z dziennikarzy, którego polityka na Zachodzie uważa za najbardziej mu sprzyjającego, kanclerz odpowiedział, że Busha. Ibidem, s. 228.

${ }^{50} \mathrm{~K}$. Malinowski, op. cit., s. 255. 
celem było przekonanie głównych państw Zachodu do wywarcia silniejszej niż dotąd presji na Kohla.

Na początku marca minister Skubiszewski wystosował listy do szefów dyplomacji wszystkich krajów graniczących z RFN, w których powtórzył postulaty sformułowane przez Mazowieckiego. Nie wysłano go jedynie do Paryża, ponieważ już wcześniej pismo niemal identycznej treści wystosował sam premier. Z krajów graniczących z RFN najistotniejsza była właśnie Francja, mająca uczestniczyć w pracach konferencji 2+4. Dlatego kolejnym celem akcji dyplomatycznej Warszawy stał się Paryż, gdzie udała się delegacja, w której skład obok premiera Mazowieckiego wszedł też prezydent Jaruzelski. Do ich rozmowy z prezydentem Francji François Mitterandem doszło 9 marca, a zatem nazajutrz po uchwaleniu wspomnianej rezolucji przez Bundestag. ,Zjednoczeniu nikt nie jest w stanie zapobiec - nie rzuci się przecież na Niemcy bomby atomowej" - stwierdził ironicznie na wstępie Mitterand, dodając zarazem, że w każdej rozmowie, jaką odbywał z Kohlem, mówił mu, iż „zjednoczenie będzie niemożliwe bez potwierdzenia, że granica na Odrze i Nysie jest ostateczna. Kohl uparcie zachowywał swoją metodę - prywatnie przyznając słuszność, ale publicznie nie angażując się". Gdy gen. Jaruzelski próbował przekonywać Mitteranda, że cztery mocarstwa mają swoje uprawnienia wobec Niemiec i w związku z tym ,możliwy jest scenariusz «coś za coś»»", usłyszał w odpowiedzi, że jest to

[...] teoretyczny punkt widzenia. Historia tymczasem została już napisana. Faktem o dużym znaczeniu było cofnięcie się Związku Radzieckiego. W tej sytuacji nie można iść za daleko. Nie ma dziś możliwości, aby czynniki zewnętrzne mogły mieć wpływ na zjednoczenie Niemiec. Z jednym wyjątkiem - nienaruszalności granic i związanych z tym gwarancji.

Z kolei Mazowiecki próbował przekonać prezydenta Francji, że sposób zagwarantowania granicy na Odrze stanowi wstęp do odpowiedzi na fundamentalne pytanie: „Czy Niemcy będą europejskie, czy też Europa będzie pod wpływami czy dominacją Niemiec?" Odpowiedź Mitteranda była w istocie przyznaniem się do bezradności w obliczu stanowiska Moskwy i Waszyngtonu: „Zgadzam się, ale działać można przy użyciu tego, czym się dysponuje. [...] ze strony Rosji i Stanów Zjednoczonych widzimy swego rodzaju wycofywanie się. Wczorajsi żandarmi wracają do siebie i czynią to bardzo szybko".

Towarzyszący Mitterandowi premier Michel Rocard zaproponował polskiej delegacji, by spróbowała porozumieć się z władzami NRD: „Podejmując rozmowy z NRD, Polska postawi Kohla w trudnej sytuacji”. Rada ta jednak - w sytuacji gdy 18 marca w NRD miały się odbyć wybory parlamentarne - nie była wiele warta i Mazowiecki powołał się na swoją rozmowę z premierem Modrowem, który na pytanie, czy po wyborach państwo to będzie jeszcze zdolne do jakichkolwiek negocjacji, miał odpowiedzieć, że „ma taką nadzieję, ale pewności nie ma”. Przyznał też, że efekt sondażu na temat polskich postulatów w Pradze wypadł niezbyt zachęcająco: „Oni proponują nasz udział [w konferencji 2+4], ale sami nie są zainteresowani udziałem”.

Mimo widocznego pesymizmu Mitteranda co do szans skutecznego przeciwstawienia się RFN zadeklarował on jednoznacznie poparcie Francji zarówno dla udziału 
Polski w części konferencji 2+4 dotyczącej granic, jak i zawarcia jeszcze przed zjednoczeniem Niemiec międzynarodowego układu gwarantującego granicę na Odrze. Nie ukrywał jednak, że presja w tej sprawie będzie skuteczna, tylko jeśli wywrą ją na Bonn wszystkie cztery mocarstwa. „Związek Radziecki - tak, Francja - tak. Ale czy zrobią to Stany Zjednoczone? One ryzykują, że narażą się Niemcom. Anglia też podlega presji USA" - oceniał francuski prezydent, na co Mazowiecki poinformował go o przebiegu swej rozmowy z Thatcher i wyraził opinię, że ,jeśli ZSRR, Francja i Wielka Brytania powiedzą tak, to czwarte mocarstwo też się wypowie”. „To możliwe, ale nie pewne" - stwierdził Mitterand ${ }^{51}$. Oficjalne poparcie udzielone polskiemu rządowi na konferencji prasowej przez Mitteranda mocno poruszyło kanclerza RFN. „Kohl reaguje z wyraźną irytacją i rozczarowaniem. Widoczne stają się dla niego granice przyjaźni z Francją" - zanotował w swoich pamiętnikach Horst Teltschik ${ }^{52}$.

Dwanaście dni po spotkaniu w Pałacu Elizejskim Mazowiecki znalazł się w Białym Domu, gdzie w bezpośredniej rozmowie z George’em Bushem mógł zweryfikować swoją ocenę sytuacji.

Jest między nami mała różnica - stwierdził 21 marca prezydent USA - nie różnimy się co do nienaruszalności granic. Ale ja jestem głęboko przekonany, że Kohl rozumie potrzebę utrwalenia istniejących granic. [...] Nie sądzę, by zjednoczone Niemcy były mniej gotowe do negocjacji w przyszłości. Kohl w swoim wysiłku do zjednoczenia nie jest zainteresowany znalezieniem gwarancji, których Pan pragnie. [...] Jestem przekonany, że wrażenie, że się w tej sprawie ociąga - wynika z wewnętrznych problemów.

Jedynym gestem pod adresem polskiego premiera ze strony Busha, który zajął otwarcie proniemieckie stanowisko, była propozycja rozpoczęcia tajnych prac nad tekstem przyszłego traktatu granicznego.

Podczas drugiej rozmowy z Bushem, odbytej następnego dnia, pojawiła się kwestia obecności wojsk radzieckich w Polsce i na obszarze NRD. Mazowiecki stwierdził: „My chcemy, żeby one wyszły z Polski. Ale bez ostentacji, pragmatycznie. Wierzę, że jak będzie redukcja do poziomu 195 tysięcy, to będzie to możliwe". Mazowiecki nawiązywał w ten sposób do zgłoszonej w tym czasie propozycji, by do takiej właśnie skali ograniczyć wielkość radzieckiego kontyngentu wojskowego przebywającego w Niemczech wschodnich, za pozostawieniem którego polski premier się opowiadał. Odpowiedź Busha była jednak negatywna: „Uważam, że wszystkie wojska radzieckie powinny wyjść. [...] Nie naciskam pana na zmianę stanowiska, ale chcę, żeby pan zrozumiał, że jeśli wojska radzieckie się wycofają, a nasze zostaną (a zostaną), to nie będzie to zagrożeniem dla nikogo". Mazowiecki zareagował na to tak: „Publicznie zapowiedziałem, że zaczniemy rozmowy na ten temat. Ale nie chcę z tego robić narzędzia nacisku na Gorbaczowa”. Znamienne, że polski premier, broniąc swojej polityki, nie posłużył się w tym przypadku argumentem o braku jasnej

51 APRP, sygn. 28/4, Zapis z rozmów w czasie oficjalnej wizyty w Paryżu (9 marzec 1990), k. 171-200.

${ }^{52}$ H. Tel t s c hi k, 329 dni. Zjednoczenie Niemiec $w$ zapiskach doradcy kanclerza, Warszawa 1992, s. 142. 
deklaracji Kohla w sprawie granicy zachodniej Polski, ale uznał, że Gorbaczowowi może zaszkodzić już samo rozpoczęcie negocjacji z Polską na temat wyprowadzenia wojsk. Bush, najwyraźniej zaskoczony sposobem rozumowania szefa polskiego rządu, ograniczył się do zakończenia tego wątku rozmowy obietnicą, że „nie będę o tym mówił, aby prasa nie doszukiwała się między nami sprzeczności”. Prezydent USA podsumował też następująco polski postulat dotyczący traktatu: „Nie ma całkowitej jasności między nami. Traktat z dwoma rządami, z których jeden nie będzie istnieć? Po co?". Zaakceptował natomiast udział przedstawiciela Polski w konferencji 2+4, ,jak będą omawiane sprawy Polski" "53. Zważywszy jednak na to, że rząd RFN - wobec zgodnego stanowiska Moskwy, Paryża i Londynu - zgodził się na to już tydzień wcześniej, nie było to dla Mazowieckiego specjalne pocieszenie.

W swoich wspomnieniach Bush napisał później: „Nie odpowiadała mi koncepcja pozostawienia wojsk sowieckich w NRD. Aczkolwiek Mazowiecki chciał, by tam zostały, nie przypuszczałem, by naród polski zbyt długo popierał takie pomysły"54. Z kolei Tadeusz Mazowiecki podczas posiedzenia rządu tak skomentował tę rozmowę z Bushem: „Odniosłem wrażenie, że prezydent jakby uważa, że my wykazujemy tu za wielką nieufność, skoro oni [RFN] chcą podpisać już po zjednoczeniu, to dlaczego my chcemy koniecznie parafować przed zjednoczeniem?"'55 O przebiegu ich spotkania Amerykanie natychmiast też powiadomili Kohla, informując, że Bush powiedział polskiemu premierowi, że „ufa kanclerzowi, i Mazowiecki też powinien ufać”56.

W końcu kwietnia 1990 roku rząd Mazowieckiego przesłał wszystkim państwom uczestniczącym w konferencji $2+4$ projekt polsko-niemieckiego traktatu zwierający opis istniejącej granicy na Odrze i Nysie Łużyckiej, wraz z formułą o jej nienaruszalności i wyrzeczeniu się roszczeń terytorialnych ${ }^{57}$. Towarzyszyła temu propozycja rozpoczęcia trójstronnych negocjacji Polska-RFN-NRD na temat przedstawionego projektu. Mimo pozytywnej reakcji nowego rządu NRD, który po wyborach do Izby Ludowej powołał Lothar de Maizière, stanowisko Bonn pozostało niezmienne. Trzy tury rozmów, do jakich doszło w maju na szczeblu dyrektorów departamentów politycznych MSZ, pokazały, że rząd RFN nie wyjdzie poza zapowiedzianą jeszcze w marcu formułę jednobrzmiącej rezolucji Bundestagu i Izby Ludowej NRD. Uchwalono ją 21 czerwca 1990 roku, przy czym w Bundestagu poparło ją 487 deputowanych, przy 15 głosach przeciwnych (z CDU/CSU) i trzech wstrzymujących się. Rezolucja potwierdzała „nienaruszalność istniejącej granicy teraz i w przyszłości" i zawierała deklarację wyrzeczenia się wszelkich roszczeń terytorialnych ${ }^{58}$.

Przyjęcie rezolucji było największym ustępstwem strony niemieckiej od chwili rozpoczęcia sporu, ale i tak nie zadowoliło to rządu Mazowieckiego. 3 lipca minister Skubiszewski wystosował bowiem notę do szefów dyplomacji państw uczestników

\footnotetext{
53 Polska wobec zjednoczenia..., s. 240-244.

54 G. Bus h, B. Scow croft, op. cit., s. 59.

${ }_{55}$ AKPRM, bez sygn., Zapis przebiegu obrad posiedzenia Rady Ministrów z 2 kwietnia 1990 r., s. 11.

${ }^{56}$ H. Telts chik, op. cit., s. 150.

57 Projekt traktatu zob. Polska wobec zjednoczenia..., s. 247-249.

58 Tekst rezolucji zob. L. Ko ć w in, op. cit., s. 141-142.
} 
konferencji 2+4, w której zaproponował, aby zawarcie traktatu polsko-niemieckiego było ,skoordynowane w czasie" z wejściem w życie układu znoszącego uprawnienia czterech mocarstw wobec Niemiec i „nie było od niego późniejsze"59. W RFN polskie stanowisko uznano za przejaw dążenia Warszawy do opóźnienia procesu zjednoczeniowego. W rezultacie już 13 lipca rzecznik rządu Małgorzata Niezabitowska zmuszona była podkreślać, że Polska nie zamierza wstrzymywać zjednoczenia Niemiec, a jedynie dąży do zgrania w czasie zakończenia konferencji $2+4$ i podpisania traktatu granicznego ${ }^{60}$.

Kohl, który w tym czasie finalizował rozmowy z Gorbaczowem, uzyskując ostatecznie jego zgodę na objęcie udziałem w NATO całego terytorium zjednoczonych Niemiec ${ }^{61}$, nie miał zamiaru zgadzać się na polską propozycję w sytuacji gdy udało mu się pokonać ostatnią poważną przeszkodę. Odrzucając propozycję Skubiszewskiego, zadeklarował jednak publicznie, że RFN - już powiększona o obszar między Odrą a Łabą - podpisze z Polską dwa układy: najpierw graniczny, a później o dobrosąsiedzkich stosunkach, w którym uregulowane miały zostać między innymi kwestie dotyczące praw mniejszości narodowych. Było to ustępstwo na rzecz Polski, pierwotnie bowiem w Bonn zakładano konieczność zawarcia w ramach jednej umowy spraw granicy oraz pozostałych kwestii, co zapewniało stronie niemieckiej przewagę negocjacyjną ${ }^{62}$. Inna rzecz, że tej ostatniej Niemcom i bez tego nie brakowało, czego najlepiej dowodził list Mazowieckiego do Kohla, w którym - po raz kolejny zresztą - zwrócił się o poparcie przez RFN polskich starań o redukcję zadłużenia w Klubie Paryskim. List ten nosił datę 3 lipca, a zatem tę samą, co nota Skubiszewskiego. Nie było to z pewnością celowe posunięcie, ale ta przypadkowa zbieżność dat znakomicie ilustruje realną pozycję Polski w stosunku do Niemiec na początku lat dziewięćdziesiątych. Została też oczywiście zauważona po stronie niemieckiej, czego dowodzą zapiski Teltschika ${ }^{63}$.

„Dlaczego pan mi nie wierzy?!” - miał krzyknąć do Skubiszewskiego zirytowany Genscher, uderzając przy tym pięścią w stół podczas ich spotkania w Paryżu, tuż przed rozpoczęciem kolejnej tury konferencji $2+4^{64}$. Taka była reakcja szefa niemieckiej dyplomacji na kolejne wątpliwości polskiego ministra. Ostatecznie Skubiszewski wycofał się z żądania przedłużenia uprawnień czterech mocarstw wobec Niemiec do chwili podpisania traktatu i 17 lipca wziął udział w paryskiej turze konferencji $2+4$, gdzie potwierdzono nienaruszalność granicy na Odrze i Nysie Łużyckiej oraz zadecydowano o podpisaniu polsko-niemieckiego traktatu granicznego natychmiast po zjednoczeniu Niemiec. „Osiągnęliśmy maksimum tego, co było możliwe w aktualnej sytuacji" - stwierdzał szef polskiej dyplomacji w notatce sporządzonej pod

59 Treść noty zob. Polska wobec zjednoczenia..., s. 368-371.

${ }^{60}$ Zob. A. Haj n i c z, Z soba czy przeciw sobie. Polska-Niemcy 1989-1992, Warszawa 1996, s. 82-93.

${ }^{61}$ Zob. A. von Plato, Die Vereinigung Deutschlands - ein weltpolitisches Machtspiel. Bush, Kohl, Gorbatschow und die geheimen Moskauer Protokolle, Berlin 2002, s. 362 i n.

62 Zob. K. Malinows ki, op. cit., s. 274.

${ }^{63}$ H. Telts chik, op. cit, s. 238.

${ }^{64}$ U. Albrecht, Die Abwicklung der DDR. Die 2+4 Verhandlungen. Ein Insider-Bericht, Opladen 1992, s. 112 . 
koniec lipca i oceniał, że ,szybkie znegocjowanie i wejście w życie traktatu o granicy nie powinno sprawiać już większego kłopotu"65.

Dokumenty końcowe konferencji 2+4 zostały podpisane 12 września 1990 roku w Moskwie i zawierały aż w pięciu miejscach ustalenia przesądzające o trwałości granic przyszłych Niemiec oraz wyrzeczeniu się przez nie wszelkich roszczeń terytorialnych. Co więcej, nakładały na zjednoczone Niemcy obowiązek zawarcia deklaracji o niezmienności granic w konstytucji oraz czyniły cztery mocarstwa gwarantem w tej sprawie ${ }^{66} .3$ października powstało zjednoczone państwo niemieckie, a już 14 listopada 1990 roku reprezentujący jego rząd minister spraw zagranicznych Hans-Dietrich Genscher oraz Krzysztof Skubiszewski podpisali w Warszawie traktat potwierdzający kształt istniejącej granicy polsko-niemieckiej.

Niezwykle szybkie tempo podpisania tego układu było bez wątpienia rezultatem zabiegów rządu Mazowieckiego i jego znaczącym osiągnięciem. Było też ze strony Kohla gestem poparcia dla polskiego premiera, który znajdował się wówczas na finiszu kampanii prezydenckiej ${ }^{67}$. Gestem o tyle istotnym, że również Kohl miał przed sobą wybory do Bundestagu, które odbyły się na początku grudnia, a w kampanii wyborczej musiał stawić czoło krytyce ze strony Związku Wypędzonych, który nie akceptował rezultatów konferencji $2+4$ oraz uznania granicy na Odrze i Nysie Łużyckiej, a także koalicyjnej CSU, gdzie z kolei domagano się łącznego rozwiązania wszystkich problemów polsko-niemieckich w jednym układzie, bez wyodrębniania traktatu granicznego ${ }^{68}$. Początkowo zresztą podobny postulat stawiał też sam Kohl, domagając się, by oba układy (graniczny i o wzajemnych stosunkach) zostały podpisane w tym samym czasie, ale podczas spotkania z Mazowieckim we Frankfurcie nad Odrą 8 listopada 1990 roku zgodził się ostatecznie na rozdzielenie obu terminów, co było o tyle istotne, że drugi z traktatów wymagał jeszcze kolejnych negocjacji. I w tym jednak przypadku ustępstwo Kohla nie było całkowite, ponieważ oba traktaty miały być ratyfikowane razem, a on sam zapowiedział - zaskakując Mazowieckiego, który chciał, by umowę o granicy podpisali obaj politycy na szczycie KBWE w Paryżu - że ze strony niemieckiej podpis złoży minister spraw zagranicznych i nie zrobi tego w stolicy Francji, ponieważ , [...] byłoby to odebrane jako konferencja pokojowa z Niemcami. [...] Ja rzadko podpisuję traktaty. [...] Jako kanclerz podpiszę tylko traktat $\mathrm{z}$ Gorbaczowem. Tak samo jestem gotów podpisać taki traktat z Polską, wielki traktat polityczny zwrócony w przyszłość" ${ }^{69}$. W tej ostatniej sprawie Kohl dotrzymał słowa, ale z polskiej strony podpis pod nim złożył już kolejny premier, czyli Jan Krzysztof Bielecki.

Olbrzymie zaangażowanie nie tylko ministra Skubiszewskiego, ale i samego premiera Mazowieckiego - przed którym piętrzyły się olbrzymie problemy związane

65 Polska wobec zjednoczenia..., s. 396-397.

${ }_{66}$ Zob. J. Barcz, Traktat „,dwa plus cztery” z 12 września 1990 r. a granica polsko-niemiecka, „Państwo i Prawo” 1990, nr 12.

${ }^{67}$ Zob. Dlaczego tak głosowano. Wybory prezydenckie '90, red. S. Gebeth ner, K. Ja si ew ic z, Warszawa 1993; J. Raciborski, Polskie wybory. Zachowania wyborcze społeczeństwa polskiego 1989-1995, Warszawa 1997, s. 57-115.

${ }_{68}$ Zob. D. B ingen, op. cit., s. 268.

69 Polska wobec zjednoczenia..., s. 461. 
z głębokim kryzysem gospodarczym oraz koniecznością przebudowy aparatu państwowego - rodzi pytanie, czy polski rząd słusznie poświęcił aż tyle energii i zabiegów, aby o kilka czy kilkanaście miesięcy przyspieszyć i tak nieuchronne zawarcie traktatu granicznego z RFN? Polityki Mazowieckiego bronią jego biografowie. „Z dzisiejszej perspektywy - pisze Roman Graczyk - wygląda to na politykę nazbyt może nieufną w stosunku do RFN, a z kolei nie dość śmiałą w stosunku do ZSRR. Ale byłby to typowy błąd perspektywy. Musimy tamtą politykę Mazowieckiego oceniać z pozycji, w jakiej Polska znajdowała się wtedy: pomiędzy Niemcami, które nie chcą się ostatecznie zadeklarować co do naszej granicy, a ZSRR, który umiera powoli i nikt nie wie, czy nie okaże się partnerem nieobliczalnym"70. Bardziej powściągliwy jest Andrzej Brzeziecki, który cały problem przedstawił następująco:

Starania o uznanie polskiej granicy zachodniej pchnęły Mazowieckiego do skomplikowanej gry, w której musiał argumentować, że jest za utrzymaniem wojsk radzieckich w Polsce jako gwarantem tejże granicy. Opinia publiczna początkowo zresztą podzielała ten pogląd - Polska oficjalnie podjęła problem wycofania wojsk we wrześniu 1990 roku. Zdaniem wielu zbyt późno ${ }^{71}$.

Największy znak zapytania należy istotnie postawić właśnie przy sprawie rezygnacji z natychmiastowego podjęcia rozmów z Kremlem na temat wyprowadzenia jego wojsk z Polski w lutym 1990 roku i uznawania ich obecności za dodatkową gwarancję dla skuteczności polskiej akcji dyplomatycznej w sprawie granicy zachodniej. Ewidentna niechęć Kohla wobec postulatów Mazowieckiego nie uzasadniała zaniechania w sprawie stanowiącej podstawowy warunek ugruntowania suwerenności państwa polskiego. Trudno też nie zauważyć, że problem gwarancji dla granicy zachodniej Polski, której zagrożenie przez niemiecki rewizjonizm w sytuacji międzynarodowej istniejącej w 1990 roku było mocno wątpliwe, niemal całkowicie zdominował aktywność dyplomatyczną Polski na innych polach, co łatwo zauważyć, czytając dokumenty dotyczące spotkań premiera Mazowieckiego i ministra Skubiszewskiego z przywódcami innych państw. To zaś musiało się odbić na skuteczności polskich zabiegów dotyczących pomocy gospodarczej czy też współpracy regionalnej. Na szczęście nie miało to negatywnego wpływu na starania Polski zmierzające do zbliżenia z Europejską Wspólnotą Gospodarczą, w czym stanowisko zjednoczonych Niemiec miało zasadnicze znaczenie.

${ }^{70}$ R. Graczyk, Od uwiklania do autentyczności. Biografia polityczna Tadeusza Mazowieckiego, Poznań 2015, s. 351.

${ }^{71}$ A. Brzezi e ck i, Tadeusz Mazowiecki. Biografia naszego premiera, Kraków 2015, s. 443. 


\section{BIBLIOGRAFIA}

\section{Archiwalia}

Archiwum Kancelarii Prezesa Rady Ministrów, Zapisy przebiegu obrad posiedzeń Rady Ministrów.

Archiwum Ministerstwa Spraw Zagranicznych, Szyfrogramy z ambasad PRL/RP.

Archiwum Prezydenta RP, Akta W. Jaruzelskiego.

\section{Prasa}

„Rzeczpospolita” 1989-1990.

\section{Wydawnictwa źródłowe i wspomnienia}

Albre cht U., Die Abwicklung der DDR. Die 2+4 Verhandlungen. Ein Insider-Bericht, Opladen 1992.

B u sh G., S c o w c roft B., Świat przekształcony, Warszawa 2000.

Horn G., Jak zerwano żelazną kurtynę?, „Polityka”, 21 marca 1992.

Koćwin L., Dekada przełomu. Stosunki polsko-niemieckie od czerwca 1989 do czerwca 1991. Dokumenty, materiaty, komentarze, Wrocław 1993.

Ko h1 H., Pragnąem jedności Niemiec, Warszawa 1999.

Ma zow i e ki T., Rok 1989 i lata następne. Teksty wybrane i nowe, Warszawa 2012.

Михаил Горбачев и германский вопрос. Сборник документов 1986-1991, red. А. Галкин, А. Черн я ев, Москва 2006.

Polacy i Niemcy pół wieku później. Księga pamiatkowa dla Mieczysława Pszona, red. W. P ię c i a k, Kraków 1996.

Polska wobec zjednoczenia Niemiec 1989-1991. Dokumenty dyplomatyczne, red. W. B o r od zi ej, Warszawa 2006.

Praw da M., Od wspólnoty losów do wspólnoty interesów - Polska i Niemcy w 1989 roku i dzisiaj [w:] Krzysztof Skubiszewski i dyplomacja czasów przełomu, red. M. Maruszkin, K. S załadzińs ki, Poznań 2016.

Przemówienie H. Kohla w Bundestagu z 28 listopada 1989 r., http://www.chronik-der-mauer.de/material/180402/rede-von-bundeskanzler-helmut-kohl-im-bundestag-10-punkte-programm-28-november-1989 [dostęp: 26.06.2017].

Reiter J., Jak definiujemy swa role w Europie [w:] Krzysztof Skubiszewski i dyplomacja czasów przełomu, red. M. Maru szkin, K. S załadzińs ki, Poznań 2016.

Skubiszewski P., Rozmowa z moim bratem [w:] Krzysztof Skubiszewski i dyplomacja czasów przełomu, red. M. Maru szkin, K. S załadzińs ki, Poznań 2016.

Th a t c h e r M., Moje lata na Downing Street, Warszawa 2012.

Stenogram 7 posiedzenia Sejmu w dniu 12 września 1989 r., www.sejm.gov.pl [dostęp: 10.04.2017].

Telt s c hik H., 329 dni. Zjednoczenie Niemiec w zapiskach doradcy kanclerza, Warszawa 1992.

Zmierzch dyktatury. Polska lat 1986-1989 w świetle dokumentów, t. II (czerwiec-grudzień 1989), red. A. Du d e k, Warszawa 2010. 


\section{Opracowania}

Barcz J., Traktat „dwa plus cztery” z 12 września 1990 r. a granica polsko-niemiecka, „Państwo i Prawo” 1990, nr 12.

B arc z J., Udziat Polski w konferencji 2+4. Aspekty prawne i proceduralne, Warszawa 1994.

B ing en D., Polityka Republiki Bońskiej wobec Polski. Od Adenauera do Kohla 1949-1991, Kraków 1997.

Brzezi e cki A., Tadeusz Mazowiecki. Biografia naszego premiera, Kraków 2015.

Dlaczego tak głosowano. Wybory prezydenckie '90, red. S. Gebethner, K. Ja si ew icz, Warszawa 1993.

D u dek A., Ewolucja stanowiska rząu Tadeusza Mazowieckiego w sprawie obecności Polski w Układzie Warszawskim oraz stacjonowania na jej terytorium wojsk radzieckich, „Dzieje Najnowsze” 2015, nr 4.

Du is b erg C.J., Das deutsche Jahr. Einblicke in der Wiedervereinigung 1989/1990, Berlin 2005.

Góralski W.M., Stosunki polityczne Polska-Niemcy [w:] Polacy i Niemcy na drodze do partnerskiego sąsiedztwa. Próba bilansu dziesięciolecia 1989-1998, red. D. Bingen, K. Malinowski, Poznań 2000.

Graczyk R., Od uwiktania do autentyczności. Biografia polityczna Tadeusza Mazowieckiego, Poznań 2015.

Gubrynowicz A., NRD - przegrana rewolucja? [w:] A. Burakowski, A. Gubrynowi c z, P. Ukielsk i, 1989 - Jesień Narodów, Warszawa 2010.

Haj n i z A., Z soba czy przeciw sobie. Polska-Niemcy 1989-1992, Warszawa 1996.

Janicki L., Podstawy prawne stosunków Polski ze zjednoczonymi Niemcami [w:] Wokót traktatów Polska-Niemcy, seria Biblioteka Przeglądu Zachodniego, z. 16, Poznań 1992.

J a s kułow s ki T., Pokojowa rewolucja w NRD w latach 1989-1990. Geneza - przebieg efekty, Wrocław 2007.

Kuźni ar R., Polityka zagraniczna III Rzeczypospolitej, Warszawa 2012.

Malew i z P., Polska polityka wschodnia w latach 1989-1991, Torun 2008.

Malinowski K., Polityka Republiki Federalnej Niemiec wobec Polski w latach 19821991, Poznań 1997.

Plato A. von, Die Vereinigung Deutschlands - ein weltpolitisches Machtspiel. Bush, Kohl, Gorbatschow und die geheimen Moskauer Protokolle, Berlin 2002.

R a c ib or s k i J., Polskie wybory. Zachowania wyborcze społeczeństwa polskiego 1989-1995, Warszawa 1997.

S tolarc zy k M., Niektóre problemy w stosunkach polsko-niemieckich w pierwszej połowie lat dziewięćdziesiątych [w:] Stosunki polsko-niemieckie w okresie przemian ustrojowych w Polsce, red. P. Do brow olski, Katowice 1997.

Strzelczyk J., Ucieczka ze wschodu. Rosja w polskiej polityce 1989-1993, Warszawa 2002.

To ma la M., Zjednoczenie Niemiec. Aspekty międzynarodowe i polskie, Warszawa 1991. 